\title{
Healthy Living: Tips for Staying Regular ${ }^{1}$
}

\author{
Linda B. Bobroff ${ }^{2}$
}

\section{Staying regular means avoiding constipation!}

Constipation means having a bowel movement fewer than three times a week. Stools are usually hard and can be painful to pass. Constipation is common among older adults.

\section{Why is constipation a concern?}

Over time, constipation can result in hemorrhoids, diverticulosis, and the inability to have a bowel movement.

\section{What causes constipation?}

- Not eating enough fiber

- Taking certain medications

- Limited physical activity

- Overuse of laxatives

- Dehydration

\section{How can I prevent constipation?}

- Eat foods with fiber every day.

- Stay physically active!

- Drink enough fluids every day to avoid dehydration.

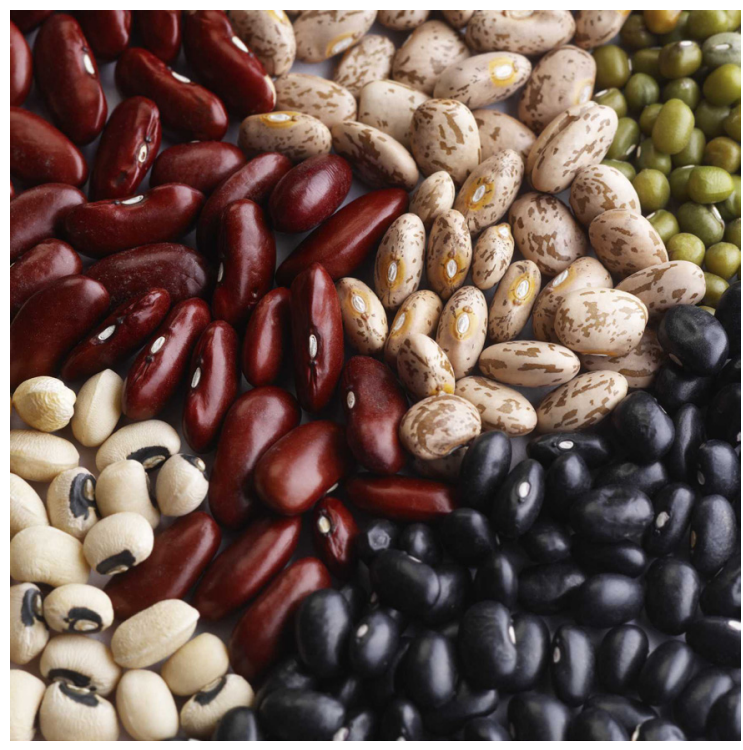

Figure 1. Legumes are great sources of dietary fiber as well as many other nutrients. Credits: Polka Dot Images

- Use a fiber supplement if you are not able to eat enough dietary fiber every day. Talk to your doctor before using fiber supplements.

\section{What foods contain fiber?}

- High-fiber cereals

- Bran muffins

- Beans (like kidney, pinto, and black beans)

- High-fiber bread

- Fruits and vegetables

- Popcorn and nuts

1. La versión en español de este documento es Vida Saludable: Manteniéndose Regular (FCS8565-Span). This document is FCS8565, one of a series of the Department of Family, Youth and Community Sciences, Florida Cooperative Extension Service, Institute of Food and Agricultural Sciences, University of Florida. First published: March 2000. Latest revision January 2013. Please visit the EDIS website at http://edis.ifas.ufl. edu.

2. Linda B. Bobroff, PhD, RD, LD/N, professor, Department of Family, Youth and Community Sciences, Florida Cooperative Extension Service, Institute of Food and Agricultural Sciences, University of Florida, Gainesville, FL 32611.

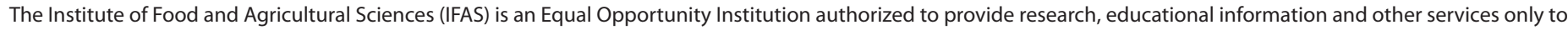

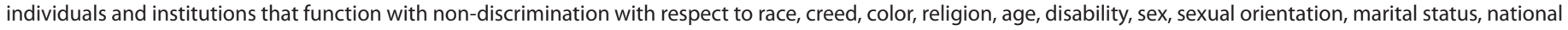
origin, political opinions or affiliations. U.S. Department of Agriculture, Cooperative Extension Service, University of Florida, IFAS, Florida A\&M University Cooperative Extension Program, and Boards of County Commissioners Cooperating. Nick T. Place, Dean 